\title{
The Process of Becoming a Professional Actor
}

\author{
Emilia Zimnica-Kuzioła \\ University of Lodz, Poland
}

DOI: https://doi.org/10.18778/1733-8069.17.3.04

Keywords:

theater actor, motives for choosing a profession, significant others, theater education
Abstract: The article concerns the process of becoming a professional actor; the author investigates the motivations of young people who decide to study acting. She is particularly interested in the impact of their significant others at various stages of the career path. The text is also an attempt to look at the stereotypes related to education in public theater schools. The empirical basis of the work involves free interviews conducted by the author with actors from Polish public drama theaters (in the period of 2015-2017) as well as journalistic interviews with theater artists published in books and popular monthly magazines in the period of 2011-2016.

\section{Emilia Zimnica-Kuzioła is an Associate Professor in} the Department of Sociology of Art, Institute of Sociology, Faculty of Economics and Sociology, University of Lodz. Her research interests include studies of art, religion and problems of contemporary culture. In the field of theater, she has carried out a lot of empirical research on theatrical audience, reception of a performance, theatrical life in Łódź and the social world of theater in Poland.

\section{Contact details:}

Department of Sociology of Art

Faculty of Economics and Sociology

University of Lodz

ul. Rewolucji 1905 r. nr 41/43

90-214 Lodz, Poland

email address: emilia.zimnica@uni.lodz.pl

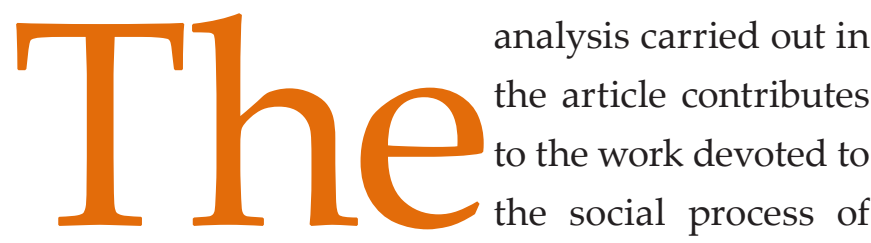
"becoming" - e.g. a cannabis smoker (Becker 1953), a doctor (Strauss et al. 1985), an employee of an industrial plant (Konecki 2007), an academic teacher (Marciniak 2008), a poet (Ślęzak 2009). In this article, I attempt at discussing the social conditions of becoming a professional actor. However, my aim is not to identify and name individual stages that lead to the crystallization of the coherent identity of the actor, but, rather, to try and answer the question about the motives for choosing this difficult profession; I will also make an attempt at investigating the role of significant others in consolidating and con- 
firming the professional self-identification of theater actors. I am interested in the socio-psychological process of identity construction with emphasis put on the significant others. The problem of identity was an important subject of scientific reflection for many theorists (including G. H. Mead, M. H. Kuhn, T. S. McPartland, R. H. Turner, W. Blumer, A. Strauss, E. Goffman, E. Erikson, S. Stryker, G. J. McCall, J. L. Simmons). It is not easy to define the concept of identity. In the literature on the subject, various terms appear, such as "self-conception," "role identity," "self-attitude," "self-image," "personal identity," "social identity," "Situational Self," etc. In general, it is about self-definition and about a relatively permanent concept of oneself, with the assumption that identity can be negotiated and susceptible to other people's influence. An important work on the subject of identity is the work by A. Strauss titled Mirrors and Mask The Search for Identity (1969). A detailed reflection on the concept of identity in the tradition of symbolic interactionism was undertaken by Andrzej Piotrowski: (1998:47-68).

My goal is also to look at stereotypes and common opinions on the subject of entrance exams to drama schools, as well as to identify the ideas and simplifying judgments regarding acting, which are not always in agreement with facts. Admission to studies and professional education, culminating in a diploma, is a turning point in the process of becoming an actor. The process of constructing identity continues, but it is intentional that my analysis here does not develop the problem of an acting career itself; this is an issue that I have devoted in another article (Zimnica-Kuzioła 2020:48-69).

It is worth emphasizing that in the Polish sociology of theater, the issue of acting is neglected and ignored. The last works concerning this theme ap- peared in the 1990s (Wilski 1990; Hera 1993). My goal is to reactivate this scientific discourse. In this, I had a cognitive purpose - I wanted to take into account the actors' perspective. My work is thus based on qualitative research techniques and I use the existing sources, namely: about 60 press and online journalist interviews with theater artists (the research sample includes all the issues of two monthly magazines from 2014 and 2015, and randomly selected issues of four other popular magazines from 2011-2016); published books (autobiographies and interviews dedicated to actors of Polish public drama theaters). I am aware of the special nature of these sources: artists' statements should be treated with caution and a critical attitude, because they are part of image creation of public figures. Undoubtedly, such sources have a greater heuristic value: in the years 2015-2017, I conducted 20 in-depth interviews with actors representing six Polish theater centers. My respondents were recruited by means of the "snowball" method; artists from both younger and older generations participated, among whom were fourteen men and six women.

In-depth interviews constitute a conversation, and the researcher does not prepare specific questions, but merely a list of issues that will be discussed. Usually, new threads appear during an interview and the researcher can follow his/her interlocutor in a completely new, previously unforeseen direction. The advantage of this research technique is openness and the possibility of an in-depth analysis of research problems. In fact, during the conversation, I was able to get to know the perspective of the research participants, their point of view, and their way of seeing reality. Most often, I conducted the interviews in theaters (a buffet, a dressing room, a rehearsal room), several conversations took place in cafes, and some others in the Institute of Sociolo- 
gy of the University of Lodz. Due to the anonymous character of my research, I do not provide details as to the theaters in which my interlocutors work, or the cities in which these theaters operate. The longest interview lasted 3 hours, while the shortest one was 45 minutes. In the process of analysis, I used qualitative content analysis.

In my work, I adopt the perspective of interpretative sociology; I am particularly interested in the symbolic interaction approach, which emphasizes the formation of a personal " $\mathrm{I}$ " under the influence of social influences. Symbolic Interactionism asks questions about the meanings that arise in everyday interpersonal interactions. In interactionism, the social world is dynamic; it is not a rigid structure, but a constantly changing one as a result of the actions of social actors. The basic conceptual category here is "the self," which is associated with the reflective ability of the individual to recognize himself/herself as the object of his/her own thinking, and the ability to perceive himself/herself. Social reality is "constructed," maintained, and transformed out of symbolic processes occurring in the course of mutual interactions between individuals and communities.

It is common that people want to be appreciated and accepted, and want to see admiration in the eyes of others (the concept of the reflected self): their subjective self changes under the influence of the assessments and opinions of persons important to them. The individual looks in the "social mirror" and what they see there greatly affects their self-knowledge and self-esteem, and the way they think about themselves.

It is not easy to answer the question about what factors determine the choice of an artistic career path.
Some theorists (e.g. the French philosopher Louis Lavelle) consider the desire to be permanently registered in the history of humanity and to gain immortality as important motivations behind artistic creativity. Ancient creators in particular strove for "posthumous fame," however, is this motivation relevant to young people nowadays? The fact is that there has been a significant increase in interest in acting studies - the high number of candidates for the first year of studies in public schools preparing for this extremely difficult profession leads to questions about the reasons for this. Józef Kozielecki (1997) introduced into the humanities the concept of hubristic explanation as a motivation to manifest one's own self and emphasize its significance, separateness, and uniqueness. Young people want to be accepted, admired, and noticed. This need used to be naturally fulfilled in primary groups, i.e. in the family and among friends. Perhaps in the era of the dominance of the virtual culture, homo internetikus does not establish cordial ties in the immediate environment and does not receive any confirmation of his/her validity. Potential fame will allow him/ her to "appear" in the minds of others. A neurotic and narcissistic personality, as Karen Horney (1981) wrote, demands attention and admiration. Certainly, many young people dream of a career in the style of Hollywood stars, i.e. achieving a high social and economic position, that would provide unlimited possibilities of consumption and "control over life." This motivation is combined with a myth that is not cited in the literature on the subject and rarely appears in the statements of the creators. However, it functions in common knowledge and opinions in the form of the myth about artists' easy life. In the popular imagination, fame translates into status and the possibilities for "the chosen ones." In fact, however, great careers involve very few artists, as most of them operate on an average financial level. Also, 
if work is their passion, and if they are guided by an internal imperative, artists put art "above other matters of life," i.e. they simply create, work intensively and are not interested in ostentatious consumption. It is characteristic that actors do not think about retirement (i.e. the time when they could "cut off coupons from fame"), as most would like to work as long as possible. Their biggest problem seems to be the fear of being forgotten:

I am the most afraid of only one thing - that one day I can be like an old rejected dog, this is the worst thing that can happen to an actor. The fear of being inefficient, unnecessary. (Interview no. 7)

In the process of creative work, theater artists can hypothetically orientate themselves to the recipient, to the work (performance), or to themselves. Considering the recipient (viewer) is an attempt to satisfy his/her supposed expectations or to convey his/her own artistic vision; considering the work involves thinking above all about creating a good spectacle, with high esthetic and ideological value; and self-respect is associated with the expression of personality, with the desire to express emotional experiences and reflections on the world, as well as with the desire to get a favorable opinion from professional critics and everyday viewers alike (see Gołaszewska 1986:200). This analytical distinction is of the ordering character, for an actor can be guided by all these considerations in one creative act.

\section{Motives for choosing the acting profession}

According to the findings of Janina Hera, in the 19th century, the decision to choose the profession of an actor was influenced by numerous factors: a genuine interest in theater as a field of art; faith in one's own talent and vocation for the profession; a desire to achieve fame and to gain importance; the desire to escape a monotonous life; a lack of prospects in life (due to a loss of property after national uprisings or having no work); being fascinated with an actress /actor appearing in a theater group; or the desire to avoid military service (employment in Warsaw's permanent theaters provided such an opportunity). For children who grew up in the theater, it was obvious that they would continue this profession: they had known no other life and would have been unable to pursue anything else. This led to a natural biographical reproduction which replicated the fate of parents (cf. Hera 1993). Young people who were questioned half a century ago (in the 1970s) about their motives for choosing the profession of an actor admitted that they had been attracted by the prospect of an interesting, intense life, as well as the opportunity to discover the truth about themselves and the realization that they had a passion (Romanowski 1978:179-190). Despite the passage of decades, the answers to the question about the motivations accompanying the choice of acting remain similar.

Jolanta Kociuba (1996:26-27) identified two basic types of motivation when choosing the acting profession: defensive one and offensive (development-oriented) one. In the first case, the individual does not accept himself/herself; his/her identity is not grounded, which is why studying and working onstage is a remedy for these deficits. "Acting can be treated as a defense mechanism, practiced out of the necessity of self-defense (defense against the lack of self-knowledge or the lack of self-acceptance)" (Kociuba 1996:26). Here, going too deep into acting roles can generate personality disintegration states. In the second case, the individual accepts himself/herself and acting is his/her way of realizing "external" 
values that are not related to the "II." There is also the possibility of combining self-knowledge and the lack of self-acceptance, since it produces interesting results and intensifies creative processes.

Offensive motivation accompanies many choices made in the acting profession. The theme of a talented child appears in numerous interviews; the actors reinterpret their own childhood in light of the present, and in their biographical discourse they uncover a continuum - they identify activities (post factum) which prepared them for their future profession: from performances in kindergarten, through reciting competitions at subsequent levels of education, to drama school and working in the theater. Talent is giftedness - innate or acquired - in a particular field, manifesting in the ability to learn quickly and with a high degree of mastery of its requirements. These are extraordinary skills, i.e. individual predispositions that must be developed, otherwise they might become dystrophic and dormant.

There is this typical story of a child who dresses up in mum's dresses, puts on high heels, and imagines a different world. Many actors showed a predisposition for this profession from a young age: "The greatest fun was creating choreography for Chopin's music. I had vinyl records, I turned the record player on, invited my grandmother, grandfather or mother, and put a show" (A41:25). Engaging in projects that "lead to acting" is a permanent feature in the biography of actors:

There was a community center of the Machulski family in the Ochota theater, my mother enrolled me in it. Then there was the Student Rehearsal Theater, in which we explored the secrets of the Stanisławski and Chekhov methods. When I look at my past now, I can see the path I have followed more or less consciously.
I didn't tell myself: "I have to be an actress." Suddenly, before graduation, it turned out that I could express myself on stage. (A42:30)

Not all actors refer to the cognitive script according to which a talented child, eager to show off and possessing personal charm, becomes an actor/ actress. Sometimes defensive motivation, related to an attempt to break with stigmatization and a desire to free oneself from complexes, is dominant. The story of one of the actors concretizes the fairy tale motif of the ugly duckling that turns into a swan. While at school, he was a small, fragile boy, and stronger students asserted their superiority over him:

I was an invisible and overlooked child [...]. Malignant friends caught me at the end of a long break and forcibly put me in a wardrobe that was standing in the hallway at school. I was afraid to jump down because I might break a bone or something [...]. I was a boy from the countryside, a bumpkin. I looked terrible - small, thin, ugly. Everything was wrong [...]. (A38:72-73).

However, when he recited poems and controlled his listeners, he was important: "I really wanted to shout to the whole world that I exist. I could only do that on stage" (A38a:72). At such moments, he felt really appreciated. In high school, he won a nationwide recitation competition, which greatly boosted his self-esteem. Thoughts of becoming an actor had occurred to him at an early stage in childhood, but his social environment did not support such aspirations. First, he was made aware of the lack of the necessary physical characteristics ("My father was afraid that I would not succeed, that only tall and handsome men succeed in this profession"); secondly, his loved ones thought that this path was in- 
accessible to "the boy from the village near Częstochowa." And yet he achieved his goals:

I live in great amazement all the time that what is happening is really happening. Then it turned out that these conditions are not so important, that other things are also important. I graduated from acting school, became an actor, and then I constantly received offers for roles in films, theater and television. And so there is this constant amazement that it this is happening all the time. (A38b)

The situation of a child from the lower social class reaching social advancement owing to great effort and great abilities breaks the vicious cycle of reproducing the habitus that Pierre Bourdieu (2005a) referred to as a "miracle." The above-mentioned artist finally said goodbye to the drama school complexes. He worked hard to prove to educators that he deserved to pursue artistic studies. With the help of books, he developed his imagination; reading was his cultural capital and it strengthened his self-esteem. The narrative of the "ugly duckling" is unique, but it should be strongly emphasized that for many actors their profession became a catalyst for change; it allowed them to stand out from the crowd, released their confidence, and enabled deep introspection. ${ }^{1}$

Regardless of the type of motivation behind choosing the acting profession - i.e. defensive or offensive - the previous considerations show that the rudimentary factor behind acting is a natural talent and an innate predisposition, which is why one of the actors states: "It's a profession for the chosen. The drama school only teaches workshops, breathing

${ }^{1}$ This is confirmed, among others, by Stanisława Celińska and Magdalena Pawlicka's 'Zacisze Gwiazd' program in the Polish TV (TVP1 online edition, March 8, 2016). techniques, etc. You must be born with the ability to play" (A38a:74). Many participants in the social world of theater confirm the common view that talent is an essential prerequisite for the acting profession:

Even as a small child I felt that I had a gift that allows me to play various roles. I remember that when I was a little boy, and I was always a little boy (laughs), when I entered the stage I was the happiest man in the world. I was a soloist in the choir, I would recite poems. I wasn't even interested what the occasion was, all I cared about was that I could perform. On stage, I wasn't a small gray man in the crowd of students, but someone important. I felt that I meant something. When I was reciting the poem and paused, there was dead silence in the room. I had the impression that I was floating two centimeters above the ground. And then I finished the poem and the whole school applauded. I was very happy then. In one such moment, I decided to become an actor. (A38c)

There are exceptions to each rule and this also applies to the process of "becoming an actor"; the story of one artist shows a different biographical variant. He was not a wonderful child; he did not dream of acting; and he did not "handle" school celebrations, reciting, and declaiming. He did not attend a club or theater center; he did not know anyone from theater circles and did not even graduate from drama school. He became interested in the theater relatively late and he found himself in theater circles due to the influence of an affectionate girl:

I took various classes. I worked in a steel mill. Then I sat in London for a while. I served breakfast and carried suitcases at the Notting Hill Gate Hotel. Then I worked at BWA. I wanted to go to Szczecin and boarded the ship. I've defined myself for a long time. 
And if it wasn't for the impulse of love, I wouldn't be an actor [...]. It was proposed that I write something. I did it and then played it. The director of the Legnica theater saw me, he thought it was good, he offered me a role in the theater. I was an apprentice for some time, then I started playing and got an invitation to join the group. I did not graduate from drama school, I passed the exam as an extramural student, years later before the ZASP commission. Beautiful time. Legnica theater was then in the avant-garde. It was a real theater work camp. Jacek Głomb built the group on the principles of the dirty dozen. Young, fantastic actors ready for anything. He led the theater out of the building: to castles, factory halls, squares and parks. Nobody did that at the time. It was happening [...]. (A1:62)

It is also worth noting that amateur actors - who are talented but have no formal theater training - are scorned by professional actors. This is not a unique situation in the social world of theater; the story told by one of the externs is indicative of a certain regularity. The actor created the first stage role in his life in a professional theater. Due to the fact that he was not a full-time employee and did not have a diploma, he came across great disapproval from the acting team and there was even a revolt. A professional colleague said that playing an amateur was "taking a hoe to the sun." He appeared onstage despite everything and that situation greatly strengthened him (A1:68). Externs must show great determination and consistency to practice this profession. An example is provided by an actress who took the drama school exams three times and was rejected each time:

The first time they rejected me because, as they said, I am already a complete and conscious actress, and they welcome people they will only be able to improve and shape. When I passed a year later, it turned out that I had an "admirer" among the university professors, he had it in for me and thanks to his efforts I did not get to the coveted faculty [...]. It was some higher reason. I don't know where that strength came from. I did what I thought was right without thinking about the consequences. From the street I found out - because someone had read the announcement - that they were recruiting at Krakow 38 Theater. I went. And what? They rejected me the first time because I had a bad day. And after a year I succeeded. (A2:78)

The woman later passed the extramural exam in order to free herself from the amateur status and fight for a higher position in the profession.

For actors who did perform on a professional stage but did so without a graduation diploma from a theater school, it became necessary to negotiate their identity. The dispute concerned the definition of "the real actor." Self-defining uncertainty forced actions aimed at confirming the concept of oneself as a fully-fledged participant in the social world of theater, i.e. one situated in its center and not on the periphery.

Currently, there is a lot of talk in the social world of theater about acting as a media temptation (e.g. Stanisz 2011:64-67). The young people filling the acting faculties of Polish state universities each year are credited with hubristic and mercantile motivations - dreams of fame and great money are said to be the main factor generating interest in this profession. However, the cited example of the artist who became an actor out of love for a girl-actress shows that sometimes interest in the profession is also determined by non-artistic considerations. 
The role of significant others at various stages of the process of becoming an actor

It is necessary to emphasize - after George Herbert Mead - the relevant role of "significant others" in the biography of the individual - these are the people influencing the individual's behavior and shaping the person's social personality and identity. In childhood and adolescence, "important others" involve parents. They influence the person's choices, behaviors, and the way of seeing the world. The child identifies with them and adopts their perspective as the only possible one. The emotionality of this relationship makes it easier to impose a definition of a situation. Primary socialization is the most important stage in human development, followed by a phase of secondary socialization. Other important people appear at this stage, influencing the individual, shaping the person's cognitive and axiological horizon, and modeling his/her behavior (Berger and Luckmann 1983:202-214; Szacka 2003:152-154).

Significant others play an important role in the professional path of all people. In the case of actors, a role-specific significant other (Denzin 1976) is usually an environmental authority that gives a clear message in terms of seeing potential, appreciating the talent, releasing energy to work, encouraging the prospective actor to take the exam at drama school, advising, confirming the decision, and supporting. Sometimes this person helps to prepare for the entrance exam, paves the way in the profession, etc. Joanna Żółkowska recalls:

My case is a confirmation of a certain, quite common rule in our environment. I became an actress thanks to a Polish teacher. The professor [...] was an unrealized director, she constantly organized performanc- es, theater groups, and I was her star. She saw me and promoted me. (2015:432)

The positive opinion of an authority from her social circle, namely Jacek Woszczerowicz, who came to her high school by special invitation, also encouraged her. Meeting him became an important event for this young girl who thought seriously about acting. The actress received great support from a significant other: "I remember that after talking with him I was unable to sleep, due to my emotions. It seemed to me that I had gained the acceptance of someone who was absolutely most important" (Żółkowska 2015:434). What is more, Woszczerowicz did not limit himself only to praising her performance, but also helped her choose texts for the entrance exams: "Indeed, he chose incredible texts, I would never have come up with them by myself. For example, I prepared Ophelia from the Wyspiański Hamlet Study. Very ambitious" (Żółkowska 2015:434).

I distinguish between five categories of people important to the professional role: the stimulator, the activator, the stabilizer, the symbolic authority, and the demotivator. What follows is their characteristics:

- the stimulator - a person catalyzing interest in Melpomen's art, noticing the potential of a young person, mobilizing the person to start theater education. She/he is not rooted in the theater environment;

- the activator - a professional providing artistic care, facilitating entry into a specific environment, and appearing on the professional stage;

- the stabilizer - a kind and supportive person fulfilling the role of a therapist and guide in 
the local social world, and knowing the specificity of the profession and environmental problems. This is the type that cushions failures;

- the symbolic authority - a mentor, a master who is a point of reference and sets the direction of professional aspirations. They cab be a physically available theater creator particularly valued by the environment, or a historical figure referred to in the environmental discourse;

- the demotivator - a person who hinders the process of building an actor's identity, cuts his/her wings, and deprives him/her of faith in the rightness of his/her own choice. Paradoxically, this type can strengthen the person's will to continue the process of becoming an actor as well as it can make the person immune to future criticism, which is inherent in public performances.

These categories emerged during the analysis of the collected empirical material, which is why they are not speculative and deductive, but strictly inductive instead. They explicitly show the social aspects of constructing a professional role. Stage actors really appreciate the help of those who contributed to the strengthening of their acting identity; it is not the case only with those whom I interviewed, as the respondents spoke a lot about their gratitude toward other participants of the social world of theater who believed in their talent, supported them in their difficulties, and facilitated their professional start.

The first category - the stimulator - is represented by people who are not rooted in the professional theater environment, but who stimulated the indi- vidual's interest in the world of theater. These can be parents, neighbors, educators, or theater instructors in community centers (sometimes with an acting school diploma). Anna Dymna described the catalyzing role of her neighbor - the actor who lived in her tenement house:

He invited me to his theater for children and youth, I played a lot of roles with him. Only I thought it was fun. Never in my life did I think I would be an actress. I couldn't imagine being on stage all my life and people staring at me and judging me. When Mr. Jan found out that I was going to take psychology, he caught me on the stairs and started shouting: "What are you thinking! You are to be a great actress, not a psychologist! Anyone can be a psychologist." And he told me to apply to PWST. So I submitted my papers for acting and psychology. (A9:26)

Dymna's parents accepted her choice, although they themselves had "solid professions." They felt that it was necessary to do that which gives satisfaction in life: "They both often said that no matter what, we must not betray our own dreams and beliefs. And here they were consistent. It is good because I love my profession very much" (A9:26). Most often, however, the stimulator is a teacher:

[A Polish teacher in high school - E.Z.K.] was the first person to notice this element in me and named it specifically. (A33:45)

In high school, I performed in a theater circle, my Polish language teacher Urszula Kraka pulled me into it almost by force. Me - the shy stuttering Arek. (A13:40)

Sometimes the significant other is the juror in a recital or theater competitions, whose good opinion is 
a decisive factor in the person taking up the acting studies:

I agree that the choice of the path that we will go on often depends on the people that fate puts in our path. Of course, I'd heard approving voices before, I collected prizes at various competitions, but there are plenty of such kids. They think I want to take acting classes, but in fact I only started to share this with the world after the words of the Master [i.e. Wojciech Młynarski, juror at the French Song Competition]. (A27:8)

The activator, in turn, is a professional who facilitates the entry into the profession in a specific theatrical environment. The support of a significant person for the pursuit of a professional role cannot be overestimated in the acting school. A professional authority indicates the direction of development, mobilizes the effort, and sometimes makes it possible for the prospective actor to appear on a professional stage when he/she is still at school. The artistic care of a master, usually a director, who engages in the performances is an extremely comfortable situation. A positive, spontaneous expression by a professor at a drama school, who positively assessed the skills of one of the actresses, helped the individual build her acting identity and boosted her confidence regarding the suitability of the chosen professional path:

I really wanted to work in this profession. I felt his magic for the first time in my fourth year. I was cast in two main roles in diploma performances [...]. I remember one day a professor came to the rehearsal while I was walking on stage with a cigarette. I pretended to do something, tried something out. She looked and said: "It's unbelievable what a feeling you have for the stage." It was a breakthrough moment. From that moment on, I slowly began to think of myself as an actress. (A41:25)
The opportunity to participate in professional ventures at the school stage eliminates uncertainty and can translate into being anchored in the social world of theater as well as into specific gratifications related to the profession: "I had the opportunity to debut in the second year with Mrs. Barbara Sass, I got good reviews, I saw that what I do makes sense. Then I received a scholarship funded by the director of the Bagatela theater, with a fulltime guarantee" (A18:55). It should be noted that today the interviewed actors regret the fact that there are fewer and fewer great individuals-artists who stimulate widespread admiration and a desire to imitate:

We were lucky to study and experience the presence of great actors, the senior members of the Polish theater scene [...]. They were people who carried a certain ethical program with them [...]. Their very presence built orientation, clarified a viewpoint and generated reflection, and it was very valuable. They taught in a drama school in a way that others certainly do not teach today. (A7:55)

In the next stage of the actor's career, when they get involved in a particular theater, the role of significant others does not diminish. This can involve authorities within theater circles, esteemed masters, superiors, or colleagues - they become guides around the local social world, offering support in difficult times. When an actor enters a new situation, it largely depends on his/her emotional intelligence whether she/he will be accepted by the group members. This is when the help of an introductory person - who minimizes the tensions associated with the interiorization of the social role - cannot be overestimated. I have called such a person the stabilizer. One actress was lucky enough to become acclimatized to the Bagatela Theater in Kraków: 
I was lost, fortunately I received a lot of support from my older colleagues. If I had found myself in a hostile environment, I would not have been able to cope. Thanks to them, it was easier for me to take my first steps, I was accepted at the beginning [...]. My group - today I can call it this - knew that a younger friend may have problems with emotions, stress and composure on stage. I received great help from Dorota Pomykała, who tried to go with me through all the stages of entering the profession. Thanks to her, I overcame successive degrees of initiation. It happened that before the premiere of the performance Dorota took me on so-called city breaks. We sat or lay down in the meadow, she said to me: "Relax, don't be nervous, it's important that the sun is shining, birds are singing, flowers are blooming." She was right, it is important in life, you can not succumb to the pressure of the upcoming premiere. These emotions pass, we cannot allow them to dominate life for a moment. I am grateful to Dorota for teaching me these principles. She took my hand, pulled me along, sometimes I even laugh that she "adopted me." (A43:51-52)

The situation is extremely comfortable when the actor can count on good advice from a competent person who knows the theater world and is kind. All artists can probably indicate such a person or people who were important from the point of view of acclimatizing the individual into the new environment (stabilizers) and boosting the person's professional development (activators). It is worth emphasizing that sometimes it is the same person who plays the stabilizing role and the activating role. Ewa Kasprzyk mentions several such people: the director Barbara Sass, whom she calls "artistic mother": "I consulted her many times when I got other suggestions from other directors (...) There is a bond between us today" (Kasprzyk and Kędziak 2013:99); Professor Ewa Lassek: “Years later, I appreciate our meeting. Student-Master. It was beautiful, difficult, sometimes strange. I know that I will remember her for the rest of my life. My professor" (Kasprzyk and Kędziak 2013:114). It is uncommon for a "mentee" to be in the orbit of a role-specific significant other on a daily basis, i.e. outside the professional context. Kasprzyk had the opportunity to live with Professor Lassek:

The professor was at a crossroads and preferred not to be alone at home. We spent a lot of time together, not only in classes, at school. These home "lectures" were in fact the real university [...]. At this home university she passed on her knowledge of acting in a natural way. Long discussions until morning in the kitchen, the analysis of poems. She made me realize the importance of verbal sphere. Maybe that's why I often pick on my younger colleagues when I don't understand what they are saying from the stage [...]. (Kasprzyk and Kędziak 2013:113)

When discussing important people (in the professional context), this particular artist also mentions a professor who played an important stimulating role: owing to him she got to the drama school (the professor believed in her very much). Before the political transformation and the expansion of the Internet, a significant other for the professional role - be it a "great actor" or a "great director" - had inspired respect and had been treated as someone special, almost a superman "from another dimension." The interviewed artists talked about this a lot, and what follows is a characteristic statement:

I remember my first entrance to the drama school when I saw Jan Łomnicki, Jan Englert, Maja Komorowska, lots of people from the screen, and I had treated them as completely isolated from life. As outstanding characters. And it remains so today, al- 
though when I once went to the toilet and met Lomnicki in it, I was shocked: "How is this? Does he have to pee too?" I couldn't understand it, but I finally felt relieved [laughs]. (A21:89)

Recalling her debut, episodic role, but one performed among great actors, Magdalena Zawadzka emphasizes the state of euphoria caused by being among eminent actors: "I was a girl, an amateur. And on the set the stars themselves: Aleksandra Śląska, Gustaw Holoubek, Andrzej Łapicki. It was like a fairy tale, like a dream" (Zawadzka 2015:420). Particularly older actors speak with great appreciation and esteem about their masters and directors with whom they collaborated. They value their working methods, talent, and a serious but friendly attitude toward the profession and their mentees alike. The master-student relationship is characteristic of artistic education. According to the interviews, however, younger actors are more restless and do not want to use the experience of older colleagues, which is a sign of our times. Meanwhile, Dorota Segda talks about the important role of mentors in the following way:

Authority in this profession is extremely important. You must have masters from the first year; observe how seriously they take theater, how they work on the role. Watch them on stage and even how they behave in a cafeteria. You can also learn a lot from them.

$(2015: 281)$

The cooperation with recognized professionals and masters is connected with the phenomenon of career coupling (Wagner 2005:22). The reputation of, for example, a director affects an actor's good reputation; a creative relationship with an outstanding person is not only a source of pride, but it can also help in achieving professional success. The famous actress emphasizes the "value of important, artistic meetings" and underlines that contact with remarkable people who taught her the theater has marked her career path. She gratefully remembers professors from her drama school - Jan Peszek, or Krzysztof Globisz, as well as directors - Jerzy Jarocki, Tadeusz Bradecki, Jerzy Grzegorzewski, and Andrzej Wajda. She also mentions her fellow actors from the 'Old Theater' [Pol. Teatr Stary] who influenced her artistic education:

Meetings with such people build the personality of a young person. Acting is not only a workshop and the ability to speak beautifully, talent alone is not enough. It should be developed and enriched. I think that even the greatest talent can be wasted if you work in a bad theater with actors that are not the best. If you don't meet masters. (Segda 2015:281)

Out of the people important for the profession, she remembers Jerzy Jarocki above all - she talks about having full confidence in the director and about his readiness for the greatest professional sacrifices:

Jarocki was the first, maybe that's why he is the most important. I played two huge roles with him at school. And then in the theater six more wonderful meetings. He shaped me incredibly. The first meeting with him was actually a kind of love. Mutual, it must be said. If he had asked me to jump out of the window, I would have jumped without hesitation. I felt like a plasticine ball in the hands of a demiurge. (Segda 2015:279)

Jerzy Jarocki is also remembered with sentiment by other actors (e.g. Jerzy Trela), who, interestingly, recall not only what was good, but also remember extremely difficult moments of cooperation with him. Therefore, it turns out that the activator does not necessarily have to strengthen the "ego" of the mentee; sometimes he/she uses the strategy of 
"a stick" rather than "a carrot." One of the artists always remembered the moment that undermined her sense of value [for an hour she tried to say one word and, according to the director, she did not do it well - E.Z.K.]: "I thought I should go to the wardrobe, take my purse, coat and never be again an actress (...) It was a test in which I felt completely destroyed by Jarocki" (A29:78). Ultimately, even difficult experiences pay off in professional life. Despite this incident, the actress emphasizes that she owes a lot to the director. She understood that every spoken word, the stage awareness, and full commitment to the production process are all important. Owing to Jarocki, she started to approach the played character intellectually and not just emotionally: "Working with him made me think logically, encouraged me to look into studies that can help prepare the role" (A29:78). The directors who shaped theater life in Poland also had a significant impact on the professional condition of many actors. The interviewed artists also consider their employers and teammates to be important people for their professional role:

I was very lucky with people. Wojtek Kościelniak, the first director of the "Capitol" Musical Theater in Wrocław, gave me my first artistic home and enrolled me in so many music and dance classes that I went to them from morning to evening. I learned a lot about acting skills working with the great Kinga Preis at the Polski Theater in Wrocław. (A3:82)

It is worth emphasizing that a significant other for the professional role may be a person that the actor has never encountered personally (a legendary actor or director): the narrative environment evokes the person's merits, acting style, great roles; the prospective actor becomes fascinated by the person's personality and artistic activities in the social world of theater. Such a figure can be a reference point, a role model, an ideal for the creator. A model image of the representative of a given profession is needed from the point of view of establishing the normative framework for action in every social world. Therefore, another category of people important for the professional role appears: a symbolic authority that inspires admiration and respect. Similarly to how a compass works, it helps to set the direction of artistic aspirations and becomes a catalyst for development.

Finally, it is worth analytically separating the category of a significant other that demotivates people - this applies to people who not only do not help, but who even hamper the role, take away actors' faith in their own abilities (Zimnica-Kuzioła 2018: 12). Many actors have encountered such an 'anti-authority' on their artistic path, e.g. Ewa Kasprzyk mentions a professor from the drama school who made a "demonic" impression on her: "I was terribly afraid of him, [...] he closed me and blocked me," she declares (Kasprzyk and Kędziak 2013:113). One of my interlocutors also did not have good memories of the theater education period:

School was one gigantic disappointment, many - now I see it, after many years - professors who had not succeeded in their professional lives, had some chips of their shoulders, some bile, who clipped our wings. Maybe there is a deeper meaning in this: "we'll see who is the toughest," maybe... but I think differently. (Interview no. 9)

The actors would have preferred to avoid meeting such "demotivators;" their devastating remarks were a real trauma for them. However, one might ask whether people who are perceived as toxic - and 
as those hindering the building of the actor's identity - ultimately contribute to the increased effort, and whether they harden young people for future criticism.

\section{Entrance exams and education in a public drama school - facts and stereotypes}

In the process of becoming an actor, passing the exam to a public drama school is an extremely important moment. Completing major studies is associated with obtaining formal legitimacy for stage work. Amateurs without a diploma have no chance of working in a theater, and the few exceptions only confirm this rule. At this point, I would like to emphasize that numerous popular opinions often do not have any grounds in the reality. Contrary to stereotypes, it is not only handsome brunettes and beautiful blondes that get into acting studios. The most important requirement is talent, the ability to attract attention, and personality. Characteristic people who do not necessarily represent the classic type of beauty also have a chance, as evidenced by the following statement:

In Warsaw I dropped out after the first stage. Warsaw chooses tall, big brunettes, with a low-set voice, and I was of a very small size and had a boy's face. My mother knows Wiesław Komasa, who was on the committee, my mother called him: "Wiesiek, you could tell me what was wrong, it could be useful for him at exams in other cities." And he told my mother that Komorowska supported me, but I was still too young, I had an unformed vocal apparatus and that I was not the type they were looking for. And he advised my mother: "Let him come to Lodz, because they are looking for weirdos." I did not blame him, because he was not malicious, he spoke with sympathy to help me. (Interview no. 10)
The next stereotype concerns the need to have 'support' in the form of a social and family capital (P. Bourdieu), i.e. connections in the social circle. There is, indeed, a phenomenon of professional reproduction, i.e. acting is often a family tradition. This can be exemplified by one of the interviewed actresses; she was being prepared for this profession since childhood, as the father was the technical manager in three theaters in Kraków, while the mother did folk dance choreography. In her teens, the actress performed at the Bagatela Theater in the play titled Blue Bird. In high school, she was involved in an inter-school theater, and then she got into the theater school at her first attempt. And - as a friend from school says about her - she was a top student (A35:76). For my interlocutor, who was exceptionally "at home" in the social world of theater, it was quite natural to choose acting as a professional path:

I am from an acting family, my mother is an actress, my father is a composer, and my stepfather is also an actor [...]. I was often in the theater, behind the scenes [...]. I often went to technical masters and electricians - I sat in the booth and watched performances from there. And I remember the theater buffet very well [...]. I lived with my mother and stepfather in a theater flat at the back of the theater. Administrative facilities and theater structure - it was my "daily bread." The actors I met in the cafeteria were simply my mother's friends, uncles, and aunts. (Interview no. 10)

However, being "at home" in the theater universe is not necessary for it to become an object of fascination or a recognized value. An actor who has had only occasional contact with the art of Melpomene can exemplify this. As a child, he used to visit theaters in Kraków with his parents (they came to performances from Andrychów, $60 \mathrm{~km}$ away), but also in his town, cultural groups from Kraków used to 
host bands sometimes (A31:98). An authentic interest in this field of art was enough to make his dreams of acting studies the reality. The lack of environmental "empowerment" can be seen as an obstacle, but this is not necessarily the case. An actress from Racibórz, although she attended a theater community in her hometown, was concerned that she would not pass the entrance exams. Her parents supported her choice, but they also did not hide their surprise that a person "without adequate resources" could become a professional actress (A43). ${ }^{2}$

Another stereotype is associated with the conviction that one must necessarily attend preparatory courses as well as practice diction in order to achieve the goal of getting into one of several public theater universities in Poland: "Considering my problems with diction, stuttering, shyness and low self-esteem, acting seemed like a dream, pie in the sky," as one of the actors stated (A13:40). He passed the course at his first attempt and is doing well in his profession. It is worth emphasizing that imperfections in theatrical skills that can be eliminated do not disqualify a potential actor.

With all that in mind, I am aware that my attempt to falsify selected stereotypes without statistical data is doomed to failure a priori. Stereotypes do not explain all events and we can always find exceptions that challenge stereotypical ideas. Therefore, I cannot invalidate the prevailing opinions based on individual examples. On the other hand, it is worth

\footnotetext{
${ }^{2}$ Joanna Stanisz - who examined the first year of students from the Acting Department of the National Film, Television and Theater School in Lodz (the beginning of studies in the academic year 2005/2006) - noted that out of 24 people only 2 came from actors' families. The researcher argued that the fact of being part of an actors' family "does not facilitate getting into school, nor does it facilitate graduation" (Stanisz 2011:282).
}

noting that there is a certain unpredictability and indeterminism in the discussed processes.

The large number of applicants for state drama schools means that it is extremely difficult to get into these dream studies the first time round. ${ }^{3}$ In the memories of many great artists, the rejection by the Examination Board is a sad experience that tested their level of determination and perseverance. One actress' statement exemplifies this well:

My profession has never let me down. The only painful event was these two failures at the entrance exams. As I tried to get into Krakow, Anna Polony told me for two years in a row that I looked like a twelve-year-old, so I could wait. Before the exams in Warsaw, I went to consultations during which I heard that I sounded bored and that I lisp. And this was right after I received the main prize at the National Festival of One Actor Theaters, where a critic wrote: "This girl interprets Bernhard even better than Łomnicki." I didn't know who to believe, I got conflicting information. After the consultation, I cried in the hallway of the drama school and thought it was over. Fortunately, I met a friend who studied there, and he reassured me that they intentionally discourage candidates in such a brutal way so that only those who truly believe in themselves would turn up for the exams. It gave me a kick to keep fighting until finally the third time I succeeded. (A8:76)

One artist who was given four bad grades at the entrance exam "for everything" was discouraged, but sticking to her choice paid off (Kasprzyk and Kędziak 2013:19). Many of the candidates rejected by the recruitment committees, who nevertheless realized

\footnotetext{
${ }^{3}$ In the mentioned study by Joanna Stanisz, the majority of the drama students - i.e. 14 out of 24 people - passed the exam at their first attempt (2011:42).
} 
their life plan, later met their examiners at work, during a performance, or on a film set. Their praise was of utmost importance to them, because it eliminated the previous - perhaps too hasty - opinion. The memory of failure from years ago was not so devaluing. It is worth noting that some candidates for actors get into university "conditionally," and during the education process they have to undertake intensive learning of pronunciation, improve diction, and strengthen self-esteem.

Cultural and economic family capital determines the way an individual functions in the education system. Pierre Bourdieu (2005b) drew attention to the phenomenon of the easier life start for individuals that come from materially-wealthy and culturally-active families. The habits of participating in symbolic culture, especially in the culture of the second system (according to Antonina Kłoskowska's concept) - acquired through the family home - pay off in the future and are a heritage that is reproduced. Some of the actors come from rural environments in which access to the so-called higher forms of cultural activity - theater, museum, philharmonic - is restricted. In fact, at the beginning of a course in a drama school, students from villages and small towns have a more difficult start, and thus have a weaker orientation in the field of artistic culture. The awareness of deficiencies forces them to make greater effort and generates the need to catch up. It is much easier for people rooted in the social environment, whose relatives or friends are connected with art and/or with the theater, not necessarily the acting profession itself.

\section{Conclusion}

The choice of the acting profession results from both defensive and offensive motives. Sometimes the decision to take exams to get into drama school is dictated by an attempt to change the negative image of oneself, is associated with the desire to break complexes. However, it is much more often the result of a long process of primary and secondary socialization. It is impossible to imagine an actor who has no natural predisposition for stage performances, i.e. talent, which is heavily valorized by the social environment. However, talent as an essential condition for professional success is not enough if it is not backed by work, support from the social circle, and the personal involvement of the individual. In many of the interviews, there was a motive of interest - already in childhood - in the phenomenon of theater. Dressing-up, performances at family celebrations, reciting poems at kindergarten and elementary school were all the beginning of this path. It must be clearly stated that many actors "inherited" talent from their parents (often also artists), but also received support from the social environment in the form of orientation and the strengthening of natural predispositions. Participation in theater groups operating in schools or community centers, visits to children's theater and then to regular theaters, conversations about art with a "significant other," and many other environmental factors all mobilize young people to start a career. The good opinions expressed by the social environment, the perception of the individual as a talented person all of this shapes the individual's self-esteem and mobilizes her/him to be active. Neither talent nor socialization would be sufficient without internal commitment and specific actions, i.e. without the individual decision and the conscious development of creative dispositions. Therefore, it is not about determination, but about the free choice of a person who makes an autonomous decision about his/her professional future. 
A similar explanation of the process of becoming an artist can be found in the work by Maria Gołaszewska, who isolated the conditions determining the realization of the creative attitude: personality conditions, social conditions, and individual conditions (1986:199). In the empirically-oriented esthetics represented by Gołaszewska, artistic creativity is the result of the disposition (creative attitude) of an individual, realized in a specific social environment. Therefore, esthetics meets sociology, because both areas emphasize the impact of exogenous factors, without which the abilities and interests of the individual would only remain in the sphere of pure potentiality. The interactive concept of "significant others" explains the mechanisms involved in the external confirmation of an individual's creative predispositions, building a professional identity.

The sociological concept of identity assumes its social bestowing, confirmation, and transformation (Berger 2012:96). “Identity is not something 'given'. But it is broadcast in the acts of social recognition. So we become what others recognize us as" (Berger 2012:97). Therefore, it is worth emphasizing that "each identity requires specific social affiliations to survive" (Berger 2012:99). If identity is processual and depends on social situations, then we can talk about its "discontinuity" and dynamics (this was the conclusion of researchers representing the Chicago school). For G. H. Mead, the significant other is a person from whom an individual adopts patterns of social behavior in the process of socialization and who influences his/her personality and identity (M. H. Kuhn used the term "orientational other"). At the stage of primary socialization, significant people consist of parents and guardians, while at the stage of secondary socialization, these are other people with whom the individual establishes lasting interpersonal relationships that serve such a role. They become a relevant point of reference for the individual.

Professional identification is very important in the process of becoming an actor. It is about a sense of bond with people involved in a specific profession, as well as about the interiorization of norms, patterns of behavior, and values specific to this profession. Many factors contribute to the development of professional identification: the attitude to the profession, motivation to work, responsibility for one's actions, satisfaction with the results of one's own involvement in the carrying out of professional tasks, etc.

In this article, I distinguished between five categories of people who are important in the dynamic process of becoming a professional actor, namely: the stimulator, the activator, the stabilizer, the symbolic authority, and the demotivator.

To become a "consecrated" actor, one needs to gain theater education, preferably in one of several public drama schools operating in Poland. The exam for a drama academy is a groundbreaking biographical fact - the beginning of an intensive process of acquiring competence for stage work. It is also the stage at which the actor acquires a role and when the actor's identity is supported by the environment. There are many stereotypes about the entrance exams to the drama school; based on my conversations with the actors, I looked at them more closely and identified phenomena that undermine the thesis about these claims' universality. Completing major studies is not only related to the acquisition of workshop skills. A diploma is a formal and symbolic sign of belonging to the professional world of theater and provides (at least potentially) the opportunity to work in one's dream profession. The analysis of 
the process of becoming an actor can be completed at this point. However, this process will continue some events will involve conscious career-building, the consolidation of the actor's identity, and an in-

\section{References}

Becker, Howard S. 1953. "Becoming a Marihuana User." The American Journal of Sociology 59(3):235-242.

Berger, Peter L. 2012. Zaproszenie do socjologii. Warsaw: Państwowy Instytut Wydawniczy.

Berger, Peter L. and Thomas Luckmann. 1983. Społeczne tworzenie rzeczywistości. Warsaw: Państwowy Instytut Wydawniczy.

Bourdieu, Pierre. 2005a. "Struktury, habitus, praktyki." Pp. 546558 in Socjologia. Lektury, edited by P. Sztompka and M. Kucia. Cracow: Instytut Wydawniczy Znak.

Bourdieu, Pierre. 2005b. Dystynkcja. Społeczna krytyka władzy sadzenia. Warsaw: Wydawnictwo Naukowe Scholar.

Denzin, Norman K. 1976. "The Significant Others of a College Population." Pp. 298-310 in Symbolic Interaction: Reader in Social Psychology, 2nd ed., edited by J. G. Manis and N. Meltzer. Boston: Allyn \& Bacon.

Gołaszewska, Maria. 1986. Zarys estetyki. Problematyka. Metody. Teorie. Warsaw: Państwowe Wydawnictwo Naukowe.

Hera, Janina. 1993. Losy niespokojnych. Warsaw: Wydawnictwo Semper.

Horney, Karen. 1981. Neurotyczna osobowość naszych czasów. Warsaw: Państwowe Wydawnictwo Naukowe.

Kasprzyk, Ewa and Maciej Kędziak. 2013. MIŁ.OŚĆ. Warsaw: Wydawnictwo G+J.

Kociuba, Jolanta. 1996. Tożsamość aktora. Lublin: Wydawnictwo UMCS. crease of his/her position in the social world of theater, while others will generate states of uncertainty and ambivalence. This, however, is a topic for another study.

Konecki, Krzysztof. 2007. "Nowi pracownicy a kultura organizacyjna przedsiębiorstwa. Studium folkloru fabrycznego." Przegląd Socjologii Jakościowej 3(1).

Kozielecki, Józef. 1997. Transgresja i kultura. Warsaw: Wydawnictwo Akademickie Żak.

Marciniak, Łukasz. 2008. "Stawanie się nauczycielem akademickim. Analiza symboliczno-interakcjonistyczna." Przegląd Socjologii Jakościowej 4(2).

Piotrowski, Andrzej. 1998. Ład interakcji. Studia z socjologii interpretatywnej. Lodz: Wydawnictwo UŁ.

Romanowski, Ryszard. 1978. "Motywy podjęcia studiów aktorskich." Kultura i Społeczeństwo 4:179-190.

Segda, Dorota. 2015. "Nie będę Julią." Pp. 269-301 in Aktorki. Portrety, edited by Ł. Maciejewski. Cracow: Społeczny Instytut Wydawniczy Znak.

Stanisz, Joanna. 2011. Aktor, artysta, człowiek - przebieg edukacji studentów Wydziału Aktorskiego Państwowej Wyższej Szkoły Filmowej, Telewizyjnej i Teatralnej w Łodzi - studium socjologiczne. Unpublished doctoral dissertation, University of Lodz, Poland.

Strauss, Anselm. 1969. Mirrors and Mask The Search for Identity. San Francisco: The Sociology Press.

Strauss, Anselm et al. 1985. Social Organization of Medical Work. Chicago, London: University of Chicago Press.

Szacka, Barbara. 2003. Wprowadzenie do socjologii. Warsaw: Oficyna Naukowa. 
Ślęzak, Izabela. 2009. "Stawanie się poetą. Analiza interakcjonistyczno-symboliczna.” Przegląd Socjologii Jakościowej 5(1).

Wagner, Izabela. 2005. "Sprzężenie karier. Konstrukcja karier w środowiskach artystycznych i intelektualnych." Przeglad Socjologii Jakościowej 1(1):20-41.

Wilski, Zbigniew. 1990. Aktor w społeczeństwie. Szkice o kondycji aktora w Polsce. Wroclaw, Warsaw, Cracow, Gdansk, Lodz: Ossoloński National Institute, PAN Publishing House.

Zimnica-Kuzioła, Emilia, 2018. Społeczny świat teatru. Areny polskich publicznych teatrów dramatycznych. Lodz: Wydawnictwo Uniwersytetu Łódzkiego.

Zimnica-Kuzioła, Emilia. 2020. “Actor's career and its determinants in the social world of professional theater in Poland." Social Contexts 8(1):48-69.

Żółkowska, Joanna. 2015. “Nie trzeba się bać.” Pp. 426-456 in Aktorki. Portrety, edited by Ł. Maciejewski. Cracow: Społeczny Instytut Wydawniczy Znak.

\section{TV Program}

Stanisława Celińska in the program Zacisze Gwiazd, Magdalena Pawlicka (online TVP1). Retrieved March 08, 2016.

\section{Press Sources}

A1: Janusz Chabior, "Niezidentyfikowane szczątki ludzkie." Zwierciadto, July 2015, pp. 58-62, conversation with Anna Serdiukow.

A2: Viola Arlak, "Gram w innych rejestrach." Zwierciadło, July 2015, pp. 76-79, conversation with Anna Serdiukow.

A3: Bartosz Porczyk, “Marzyciel.” Zwierciadło, July 2015, pp. 80-84, conversation with Marta Wróbel.

A7: Piotr Fronczewski, "Czy jeszcze mam marzenia?" Zwierciadło, January 2015, pp. 54-61, conversation with Kamila Drecka.

A8: Gabriela Muskała, "Albo dobrze, albo wcale." Zwierciadło, September 2014, pp. 74-79, conversation with Anna Serdiukow.
A9: Anna Dymna, “Chce się żyć.” Twoój Styl, November 2014, pp. 22-28, conversation with Anna Jasińska.

A13: Arkadiusz Jakubik, "Mam ci to zagrać?" Uroda Życia, August 2015, pp. 39-42, conversation with Magdalena Felis.

A18: Urszula Grabowska, "Rośnie we mnie spokój." Sens, March 2011, pp. 52-58, conversation with Alina Gutek.

A21: Artur Żmijewski, "Emocje muszą być." Sens, January 2015, pp. 86-89, conversation with Hanna Halek.

A27: Katarzyna Dąbrowska, "Ruda rządzi." Sens, March 2015, pp. 6-10, conversation with Joanna Olekszyk.

A29: Dominika Kluźniak, "Sztuka znikania." Zwierciadło, May 2014, pp. 75-80, conversation with Remigiusz Grzela.

A31: Jan Peszek, "Całe życie po swojemu." Zwierciadło, May 2014, pp. 96-101, conversation with Hanna Halek.

A33: Katarzyna Maciąg, "Teraz mogę być każdym." Sens, March 2014, pp. 42-45, conversation with Hanna Halek.

A35: Dorota Kolak, "Jak przestałam być świętą Zuzanną." Zwierciadło, March 2014, pp. 73-76, conversation with Małgorzata Wach.

A38a: Artur Barciś, "Czekając na oklaski." Zwierciadło, September 2015, pp. 70-75, conversation with Maciej Gajewski.

A38b: Artur Barciś, "Zawsze reaguję uśmiechem," conversation with Anna Chodacka. Retrieved August 10, 2015 (http://kobieta.interia.pl/gwiazdy/wywiady/news-artur-barcis-zawsze-reaguje-usmiechem).

A38c: Artur Barciś, “Już nie mam kompleksów.” Retrieved August 10, 2015 (http://kobieta.interia.pl/gwiazdy/wywiady/news-artur-barcis-juz-nie-mam- kompleksow),

A41: Anna Korcz, "Spokojnie siedzę na brzegu." Skarb, November 2015, s. 24-27, conversation with Agata Młynarska.

A42: Agnieszka Grochowska, "Nie lubię mówić: ja, ja, ja." Skarb, November 2015, s. 28-31, conversation with Agnieszka Święcicka.

A43: Magdalena Walach, "Szczęściara." Zwierciadło, April 2015, pp. 46-52, conversation with Anna Serdiukow. 


\section{Citation}

Zimnica-Kuzioła, Emilia. 2021. “The Process of Becoming a Professional Actor.” Przegląd Socjologii Jakościowej 17(3):76-95. Retrieved Month, Year (www.przegladsocjologiijakosciowej.org). DOI: https://doi.org/10.18778/1733-8069.17.3.04

\section{Proces stawania się zawodowym aktorem}

Abstrakt: Celem artykułu jest rekonstrukcja procesu stawania się zawodowym aktorem. Autorka stawia pytanie o motywacje, jakie kierują młodymi ludźmi decydującymi się na studiowanie aktorstwa. Interesuje ją także oddziaływanie znaczących innych na różnych etapach drogi prowadzącej do zawodu. Tekst stanowi też próbę przyjrzenia się stereotypom dotyczącym egzaminów wstępnych i edukacji w publicznych szkołach teatralnych. Bazę empiryczną pracy stanowią wywiady swobodne przeprowadzone przez autorkę z aktorami polskich publicznych teatrów dramatycznych (w latach 2015-2017) oraz wywiady dziennikarskie z artystami teatralnymi opublikowane w pozycjach książkowych i popularnych miesięcznikach w latach 2011-2016.

Słowa kluczowe: aktor teatralny, motywacje wyboru zawodu, znaczący inni, edukacja teatralna 